Teknomekanik

Vol.3, No.2, December 2020, pp. 36-42

e-ISSN: 2621-8720 p-ISSN: 2621-9980

\title{
The Effect of Current Strength Towards ABREX Steel 400 Pulling Strength by Using SMAW Welding with Electrode E7018
}

\author{
Muhammad Rizki ${ }^{1 *}$, Nelvi Erizon ${ }^{2}$, Budi Syahri ${ }^{3}$ \& Rodger Eliab $\mathrm{Jr}^{4}$ \\ 1,2,3 Jurusan Teknik Mesin, Fakultas Teknik, Universitas Negeri Padang, Indonesia \\ ${ }^{4}$ Electrical Department, Iloilo Science and Technology University, Philippines
}

\begin{tabular}{l}
\hline Article Info \\
\hline Article history: \\
Received July $22^{\text {th }}, 2020$ \\
Revised Aug $19^{\text {th }}, 2020$ \\
Accepted Nov $25^{\text {th }}, 2020$ \\
\hline
\end{tabular}

\section{Keywords:}

Welding Current

Tensile Strength

SMAW

ABREX Steel 400

E7018

\section{Corresponding Author: \\ Muhammad Rizki, \\ Jurusan Teknik Mesin, Fakultas Teknik, Universitas Negeri Padang \\ Jln. Prof. Dr. Hamka Air Tawar, Padang (25131) Sumatera Barat, Indonesia \\ Email: teukumuhammadrizki20@gmail.com}

\section{INTRODUCTION}

The growth of technology in the construction field which is rapidly developing cannot be separated from the welding. The fabrication of the current metal construction involves a lot of welding elements, especially in the designing field because welding joints are one of the jobs that technically require high skills in order to obtain a connection with good quality [1]. Tensile testing plays an important role in evaluating the basic nature of engineering materials as well as in developing new materials and controlling material quality for being used in the design and construction [2]. In fact, welding is a process of connecting two or more pieces of metal by heating or pressing or merging them together like a solid object 3]. Welding is a technique used to combine two or more components based on the principle of the diffusion process [4]. Welding can be defined as a metal recrystallization process with or without added materials using heat energy as a liquefaction of the material being welded, in other words a fixed bonding of the object or metal which is being heated. This welding process is widely used in the maintenance and repair industry, steel structure construction and the fabrication industry [5]. SMAW welding is an electric arc welding where heat is generated from an electric arc between the tip of the electrode and the metal being welded [6]. The base metal in this welding experiences liquefaction caused by the heat of the electric arc that arises between the tip of the electrode and the surface of the work piece. The electric arc is generated from a welding machine. The electrode used is a wire wrapped in a protective flux. The function of the flux layer or electrode on the weld is to shield the molten metal from the air environment to produce a protective gas and stabilize the arc, the source of the alloying element [7].

The input parameters which are mainly responsible for welding penetration are welding current, welding voltage, welding speed and these parameters play a role in achieving the desired penetration in the weld joint [8]. The adjustment of the welding current strength is important because it will affect the weld result [9]. The use of welding current which is too low will cause the difficulty in igniting the electric arc and it can cause an unstable electric arc [10]. In addition, the heat generated is not sufficient to melt the electrode and the base 
material, resulting in small and uneven welds and deep penetration [11]. Vice versa, if the welding current is too high, the electrode will melt too quickly and this will result in a wide surface and deep penetration resulting in low tensile strength and increasing the brittleness of the welding result [12]. Technically, it requires high skill for a welder to get a good weld joint and welding quality. The required welding current depends on the electrode diameter, the thickness of the metal being welded, the type of electrode used, and the welding position [13].

The research on welding current strength has been carried out by several researchers, one of them is Agung [14] who conducted the study with the aim to identify the effect of electric current on the tensile strength of low carbon steel, the results showed that the quality of the weld joint can be obtained with good results if the current used is appropriate according to the welding parameters. Pebrian [15] has conducted a research to determine the effect of welding current on the hardness of low carbon steel weld joints, the results showed that there are a lot of differences in the hardness value of each specimen, and the maximum hardness is obtained at the current $130 \mathrm{~A}$. The properties of carbon steel depend on the amount of its carbon content which is widely used in engineering practice [16]. ABREX 400 steel is categorized as low carbon steel because of its carbon content $<0.3 \%$, which is widely used for heavy structural steel work [17]. Meanwhile, low carbon steel is the most common form of steel because of its relatively low price and superior mechanical properties such as tensile strength and toughness, and it is acceptable for many engineering applications [18]. Based on the background above, this research discusses the effect of welding current on the tensile strength of the ABREX 400 low carbon steel welded joints after being welded by the SMAW process using 7018 electrodes.

\section{METHOD}

The method used was the experimental research method in which the object of the research was the welding joint of ABREX 400 steel plate with a thickness of $10 \mathrm{~mm}$ as the result of SMAW welding with electrode E7018 Ø3.2 mm. additionally, the connection used was a single $\mathrm{V}$ groove connection with a welding position of $1 \mathrm{G}$. The treatment given was providing three variations of welding current, those are $90 \mathrm{~A}, 100 \mathrm{~A}$, and $110 \mathrm{~A}$.

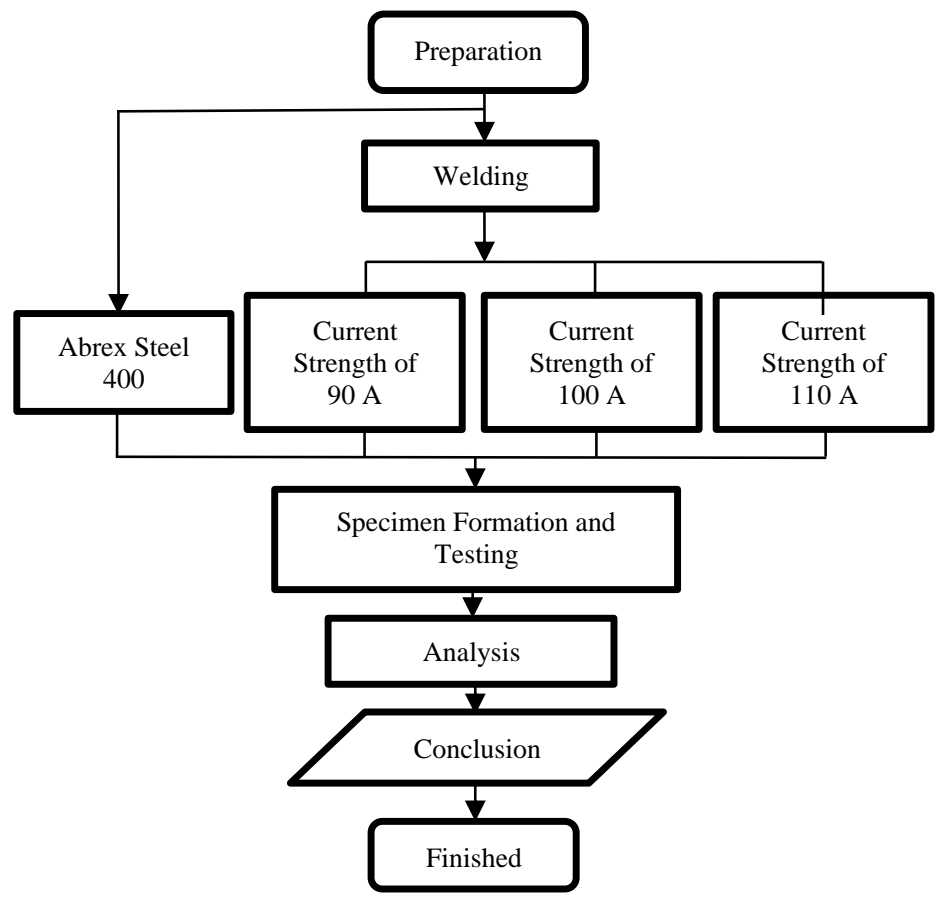

Figure 1: Research Diagram

The tensile testing process was carried out three times for each test specimen. Tensile test was a type of destructive test [19]. In addition, this type of testing was carried out on the specimen until it was damaged [20]. The working principle of the tensile test was carried out by using a static load that was given gradually until the specimen broke. Several mechanical properties that could be obtained from the results of the tensile test were tensile strength, brittleness, and ductile. These properties could be obtained from the stress-strain curve results of the tensile test carried out by the process of drawing the material until it is broken [21]. 


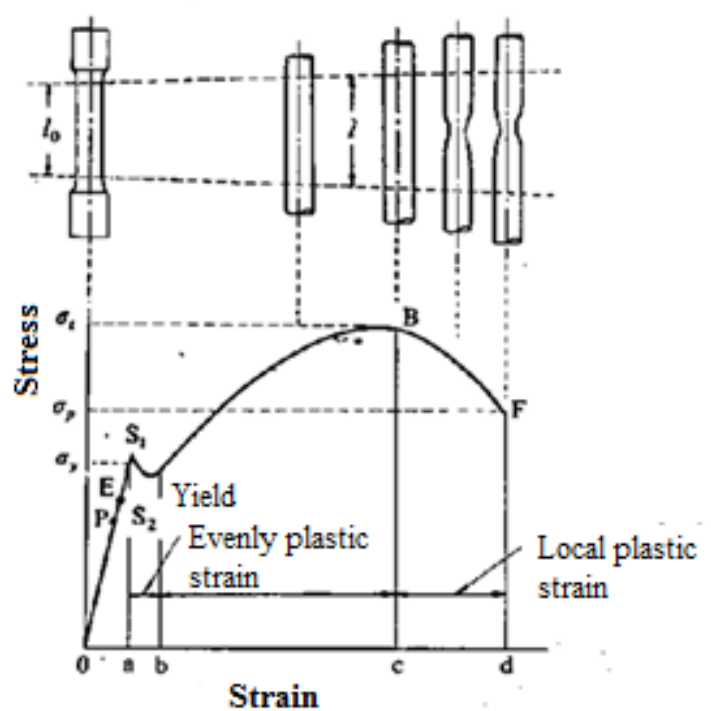

Figure 2 : Stress and Strain Curves [21]

In the tensile test, the load was given continuously, slowly and constantly, and at the same time, the observation was carried out on the elongation that was experienced by the specimen and a stress-strain curve was generated. To determine the value of the tensile strength from the material $(\sigma)$ the value of the maximum force $(\mathrm{F})$ was divided by the cross-sectional area $\left(\mathrm{A}_{\mathrm{o}}\right)$ (equation 1 After obtaining the tensile strength value, the strain value $(\varepsilon)$ was determined through the final length of the test material $\left(\mathrm{L}_{\mathrm{i}}\right)$ minus the initial length of the material before the testing $\left(\mathrm{L}_{\mathrm{o}}\right)$ and it was divided by the initial length of the material $\left(\mathrm{L}_{\mathrm{i}}\right)$ then multiplied by $100 \%$ (equation 2). Finally, to determine the modulus of elasticity of the material (E), the amount of tensile strength $(\sigma)$ was divided by the strain that occurs in the material $(\varepsilon)$ (equation 3 ).

$$
\begin{aligned}
& \sigma=\frac{F}{A_{0}} . \\
& \varepsilon=\frac{l_{i-} l_{o}}{l_{o}} \times 100 \% \\
& E=\frac{\sigma}{\varepsilon}
\end{aligned}
$$

\begin{tabular}{|c|c|c|c|c|c|c|c|c|c|c|c|c|c|c|c|}
\hline \multirow{3}{*}{$\begin{array}{c}\text { TIRA } \\
\text { STEEL } \\
\text { NAMES }\end{array}$} & & \multicolumn{8}{|c|}{ CHEMICAL ANALYSIS (\%) } & \multicolumn{6}{|c|}{ MECHANICAL PROPERTIES } \\
\hline & \multirow{2}{*}{$\mathrm{C}$} & \multirow{2}{*}{$\mathrm{Cr}$} & \multirow{2}{*}{$\mathrm{Ni}$} & \multirow{2}{*}{ Mo } & \multirow{2}{*}{$\mathrm{Mn}$} & \multirow{2}{*}{$\mathrm{Si}$} & \multirow[b]{2}{*}{ 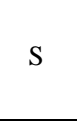 } & \multirow{2}{*}{ Pmax } & \multirow{2}{*}{ others } & \multicolumn{2}{|c|}{ UTS-Rm } & \multicolumn{2}{|c|}{$\begin{array}{l}0,2 \text { Y.S - } \\
\text { Rp 0,2\% }\end{array}$} & \multirow{2}{*}{$\begin{array}{c}\text { El } \\
- \\
\text { As } \\
\%\end{array}$} & \multirow{2}{*}{$\begin{array}{c}\text { HARDANESS } \\
\text { VALUE } \\
\text { HBN }\end{array}$} \\
\hline & & & & & & & & & & Mpa & Ksi & Mpa & Ksi & & \\
\hline TRS 400 & 0.2 & 1 & - & 0.3 & 1.6 & - & 0.005 & 0.02 & - & 1344 & 195 & 1103 & 160 & 13 & 400 \\
\hline
\end{tabular}

Table 1: ABREX 400 Steel Specifications

Table 2: Specifications for Universal Testing Machine.

\begin{tabular}{ccccc}
\hline Type & Year & Made & Capacity & No. Serial \\
\hline WAW-10000 & 2019 & China & 10000 & 180045 \\
\hline
\end{tabular}

The welding joint that was used in this research is a single $\mathrm{V}$ groove connection with a bevel angle of $30^{\circ}$. As a matter of fact, groove $\mathrm{V}$ joints were used to connect metal or plates with a thickness of 6-20 mm with a groove angle of $60^{\circ}$, root gap $0-3 \mathrm{~mm}$ and root face $0-2 \mathrm{~mm} \mathrm{[22].} \mathrm{The} \mathrm{single} \mathrm{V}$ groove was chosen due to the 
maximum UTS strength yield compared to other weld joint designs [23]. Single V groove joints was able to endure the pressure better than the other types of joints [24].

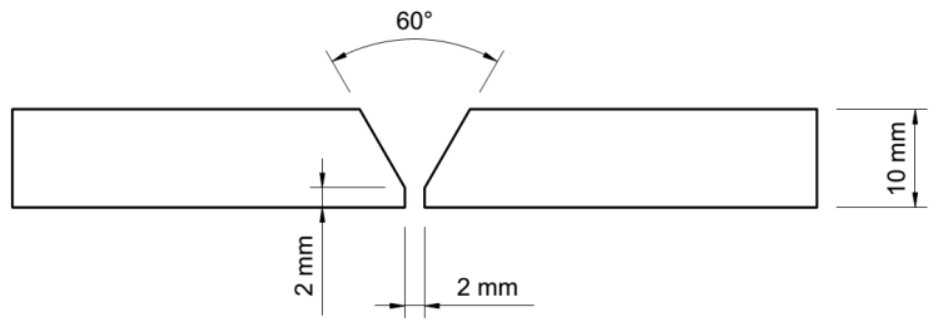

Figure 3 : Groove V [22]

After the welding process was completed, the specimen tested was levelled and the welding groove was formed into a tensile test specimen according to the ASTM E-8 standard as shown in Figure 2.

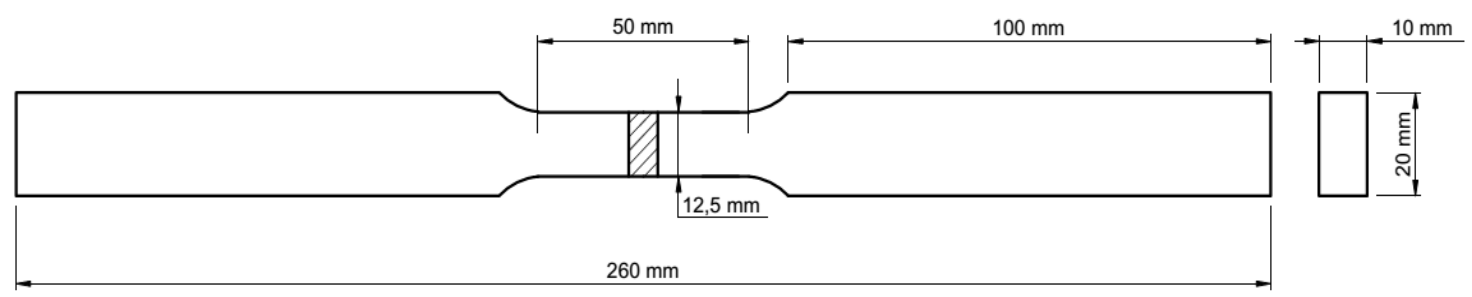

Figure 4 : ASTM-E8 Tensile Test Specimen Specification [25]

\section{RESULTS AND DISCUSSION}

The specimen used for the testing was a low carbon steel ABREX 400 type which was given the welding treatment using welding current strengths of $90 \mathrm{~A}, 100 \mathrm{~A}$, and $110 \mathrm{~A}$. The following pictures display the low carbon steel type ABREX 400 after experiencing a tensile test:

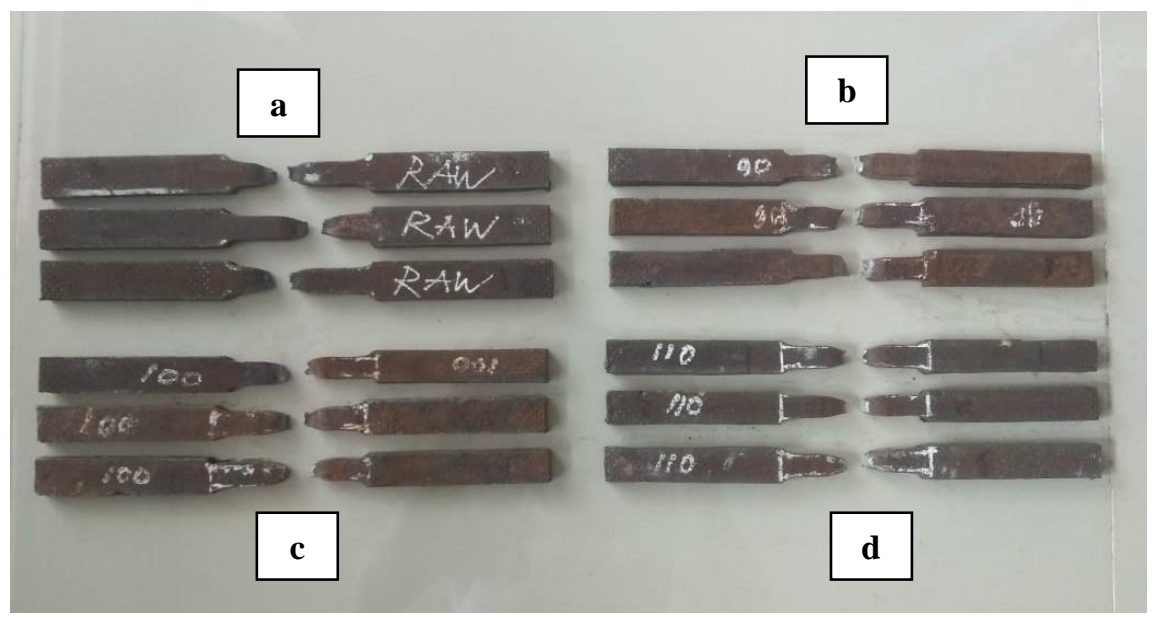

Figure 5 : Tensile Specimen After Being Tested

Figure 4. Tensile Specimen After Being Tested, (a) specimen without welding (ABREX 400), figure (b) specimen with a current of 90 A, figure (c) Specimen with a current of 100 A, figure (d) Specimen with a current of $110 \mathrm{~A}$. In figure (a), the specimens without the welding revealed the uneven breaking points. This issue occured because the specimens were not given the special treatment. Whereas in Figure $(b, c, d)$ all specimens experienced a break point in the weld joint or weld area. This corresponded to the steel strength of 
ABREX 400 which was higher at $1091.47 \mathrm{~N} / \mathrm{mm}^{2}$ than the electrode strength of E7018 which was only 70,000 Psi or $482.63 \mathrm{~N} / \mathrm{mm}^{2}$.

Table 3 : Average Tensile Test Results

\begin{tabular}{ccccc}
\hline \multirow{2}{*}{ Current Strength } & \multicolumn{4}{c}{ Specimens $\left(\mathrm{N} / \mathrm{mm}^{2}\right)$} \\
\cline { 2 - 5 } & 1 & 2 & 3 & Average \\
\hline ABREX Steel 400 & 1090,08 & 1080,16 & 1104,16 & $\mathbf{1 0 9 1 , 4 7}$ \\
$90 \mathrm{~A}$ & 593,92 & 588,32 & 584,48 & $\mathbf{5 8 8 , 9 1}$ \\
$100 \mathrm{~A}$ & 584,16 & 578,4 & 549,12 & $\mathbf{5 7 0 , 5 6}$ \\
$110 \mathrm{~A}$ & 560,96 & 532,16 & 542,4 & $\mathbf{5 4 5 , 1 7}$ \\
\hline
\end{tabular}

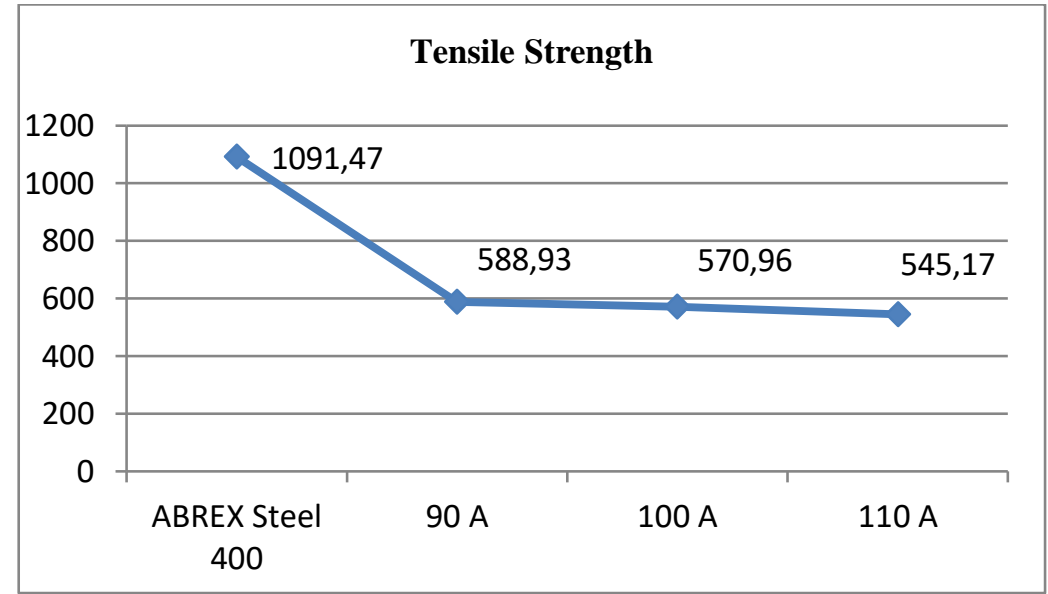

Figure 6: Comparison Chart of Specimen Tensile Strength

Based on the data obtained from the results of the tensile test, the control specimen produced a tensile strength of $1091.47 \mathrm{~N} / \mathrm{mm}^{2}$. In fact, at a welding current of $90 \mathrm{~A}$, the control specimen produced a tensile strength of $588.91 \mathrm{~N} / \mathrm{mm}^{2}$, and when the welding current is at $100 \mathrm{~A}$, it was able to generate a tensile strength of $570,56 \mathrm{~N} / \mathrm{mm}^{2}$. Furthermore, the control specimen produced a tensile strength of $545.17 \mathrm{~N} / \mathrm{mm}^{2}$ at the welding current of $110 \mathrm{~A}$. From these data, it can be seen that the highest tensile strength is found in the welding current strength of $90 \mathrm{~A}$, with an average tensile strength value of $588.91 \mathrm{~N} / \mathrm{mm}^{2}$. While the lowest tensile strength value is found at the welding current of $110 \mathrm{~A}$, with an average value of $545.17 \mathrm{~N} / \mathrm{mm}^{2}$ of tensile strength. The graph in Figure 9 shows that each object has a different tensile stress. In addition, this graph is a comparison of the average tensile strength of each specimen. Thus, it can be concluded that the current strength and tensile stress are inversely proportional, where the higher the welding current used, the lower the tensile stress and vice versa, the lower the welding current used, the higher the resulting tensile strength

\subsection{ABREX Steel 400}

This specimen did not experience the heat treatment in the welding process because it was aimed to be the control specimen. In fact, the control specimens had an average tensile strength value of $1091.47 \mathrm{~N} / \mathrm{mm}^{2}$ in which this tensile strength value was the highest value of all tensile test specimens because there was no welding treatment given to the control specimen, before the tensile test was carried out so that the specimen did not experience structural changes.

\subsection{The specimen being tested at a welding current strength $90 \mathrm{~A}$}

For this specimen, the SMAW welding process was carried out with a current strength of 90 A. From the results of the tensile strength test, the specimen broke at the weld joint. This specimen produced an average tensile strength value of $588.91 \mathrm{~N} / \mathrm{mm}^{2}$. This current was good enough for the root pass, fillet and capping during the welding process. 


\subsection{The specimen being tested at a welding current $100 \mathrm{~A}$}

In this specimen, the SMAW welding process was carried out with a current of $100 \mathrm{~A}$. From the results of the tensile strength test, the specimen broke at the weld joint. This specimen resulted on an average tensile strength value of $570.56 \mathrm{~N} / \mathrm{mm}^{2}$ and this sort of current was still good enough for the root pass, fillet, and capping.

\subsection{The Specimen being tested at a welding current $110 \mathrm{~A}$}

For this specimen, the SMAW welding process was carried out with a current strength of 110 A. From the results of the tensile strength test, the specimen broke at the weld joint. This specimen generated an average tensile strength value of $545.17 \mathrm{~N} / \mathrm{mm}^{2}$. This current was too high for the penetrating process but it was still good enough for the fillet and capping process.

\section{CONCLUSION}

Based on the data analysis and discussion on the tensile testing in this research, it can be concluded that the results obtained from the tests on low carbon steel material ABREX 400 with different current strengths showed that the welding current strength affected the strength of the material. Meanwhile, the results of the welded joint from the tensile test revealed that the specimen broke in the weld area. This result indicates that there was an unsuitable electrode in combining ABREX 400 steel when it was viewed from the mill certificate or a defect in the welding process. The highest tensile strength was found in the welding current strength of 90 A, with an average tensile strength of $588.91 \mathrm{~N} / \mathrm{mm} 2$. While the lowest tensile strength value was found at the welding current of $110 \mathrm{~A}$, with an average value of $545.17 \mathrm{~N} / \mathrm{mm} 2$ of tensile strength. Thus it can be concluded that the current strength and tensile stress are inversely proportional, where the higher the welding current used, the lower the tensile stress and conversely the lower the welding current used, the higher the resulting tensile strength.

\section{REFERENCES}

[1] Dhabhi B R, Chauhan V D, Choksi P.G. Review for Design of Gripper in Universal Testing Machine. International Journal for Scientific Research \& Development. 2016; 4 (1).

[2] Nurdin H. Fernanda Y, Handayani, M. Analysis of Tensile Strength the Fiber Bagasse Particles Board with Resin Adhesives. Teknomekanik. 2018; 1 (1) : 1-5. Doi: 10.31227/osf.io/4zrbp

[3] Alip M. Teori dan Praktik Las. Departemen Pendidikan dan Kebudayaan. 1989.

[4] Isnugroho K. Hidayat H, Amin M. Hendronursito Y, Astuti W. Analysis of Shielded Metal Arc Welding (SMAW) On High Manganese Steel Hammer-mill Crushe. Journal of Mechanical Engineering. 2019; 16 (2) : 93-107.

[5] Refdinal, Ramli, Andesko R. Differences Strength of Low Carbon Stainless Steel St 37 with Electrical Welding Compound $\mathrm{V}$ Use Materials Add Electrodeof Type-RB and Type-RD. Teknomekanik. 2018; 1 (1) : 12-17. Doi: 10.24036/tm.v1i1.472

[6] Suharno. Prinsip-Prinsip Teknologi dan Metalurgi Pengelasan Logam. Jawa Tengah: UNS Press. 2008.

[7] Munawar et al. The Effects of Shielded Metal Arc Welding (SMAW) Welding On The Mechanical Characteristics With Heating Treatment inn S45c Steel. Journal of Physics: Conference Series. 2018. Doi: $10.1088 / 1742-6596 / 962 / 1 / 012063$

[8] Deshpande M U, Kshirsagar J M, Dharmadhikari H M. Optimization of GMAW Process Parameters to Improve the Length of Penetration in EN 10025 S 235 Grade. Journal of Welding and Joining. 2017; 32 (1) : 74-78. Doi: 10.5781/JWJ.2017.35.1.74

[9] Selvam R, Jacob S. Experimental Investigation and Analysis of Smaw Processed Carbon Steel Pipes. International Journal of Mechanical and Production Engineering Research and Development. 2018; 8 (5) : 29-40.

[10] Arifin. 1997. Las Listrik dan Otogen. Jakarta: Ghalia Indonesia. 
[11] Adedayo A V, Ibitoye S A, Oluwole O O. Tempering Heat Treatment Effects On Steel Welds. Journal of Minerals And Materials Characterization And Engineering. 2011; 10 (8) : 547557. Doi: $10.4236 /$ jmmce.2011.108059

[12] Parmar A, Dubey A. Study of heat affected zone for smaw process for low carbon steel specimen with controlled parameters. International Journal of Modern Trends in Engineering and Research. 2017; 4 (11). Doi: 10.21884/ijmter.2017.4339.cy2nc

[13] Dadi A, Goyal B, Patel H. A Review Paper on Optimization of Shielded Metal Arc Welding Parameters for Welding of (Ms) Sa-516 Gr.70 Plate by Using Taguchi Approach. International Journal of Scientific Research in Science and Technology. 2018; 4 (5) : 1536-6011.

[14] Pratomo M A, Jasman, Erizon N, Fernanda Y. The Variation Effect of Electric Current Toward Tensile Strength on Low Carbon Steel Welding with Electrode E7018. Teknomekanik. 2020; 3 (1) : 9-16. Doi: https://doi.org/10.24036/tm.v3i1.5572

[15] Jasman, J., Irzal, I., Adri, J., \& Pebrian, P. Effect of Strong Welding Flow on the Violence of Low Carbon Steel Results of SMAW Welding with Electrodes 7018. Teknomekanik. 2018; 1 (1) : 24-31. Doi: https://doi.org/10.24036/tm.v1i1.972

[16] Oluwasegun S. Odebiyi, Segun M. Adedayo, Lawal A. Tunji and Martins O. Onuorah. A Review of Weldability of Carbon Steel in Arc-Based Welding Processes. Cogent Engineering. 2019; 6 (1) : 1-32. Doi: https://doi.org/10.1080/23311916.2019.1609180

[17] ABREX ${ }^{\mathrm{TM}}$. Abrasion Resistant Steel Plates Guidelines for Welding. Nippon Steel Corporation. 2019.

[18] Yadav, Devendra \& Gaikwad, Abhishek. Comparison and Testing of Tensile Strength for Low \& Medium Carbon Steel. International Journal of Mechanical Engineering (IJME). 2015; 4 (5) : 1-8.

[19] Ameen A. Nassar, Rafil M. Lefta and Muthanna J. Abdulsada. Experimental Study of The Effect of Welding Electrode Types on Tensile Properties of Low Carbon Steel Aisi1010. Kufa Journal of Engineering. 2018; 9 (4) : 163-173. Doi: 10.30572/2018/kje/090411

[20] Didit Sumardiyanto, Sri Endah Susilowati. Effect of Welding Parameters on Mechanical Properties of Low Carbon Steel API 5L Shielded Metal Arc Welds. American Journal of Materials Science. 2019; 9 (1) : 15-21. Doi: 10.5923/j.materials.20190901.03

[21] Wiryosumarto, H., \& Okumura, T. Teknologi Pengelasan Logam. Jakarta: Pradnya Paramita. 2008.

[22] Sonawan, H., \& Suratman, R. Pengantar Untuk Memahami Pengelasan Logam. Bandung: Alfabeta. 2004.

[23] Syambabu Nutalapati, Dr. D. Azad and Dr. G. Swami Naidu. Effect of Welding Current on Welding Speed and Ultimate Tensile Strength (UTS) of Mild Steel. International Journal of Mechanical Engineering and Technology. 2016; 7 (5): 156-176.

[24] İpek, Nazlı \& Elaldi, Faruk. Analysis of Welding Groove Angle and Geometry on Strength of Armor Steel. Materials and Manufacturing Processes. 2012; 27:12, 1437-1441. Doi: $10.1080 / 10426914.2012 .709343$

[25] ASTM E8/E8M. Standard Test Methods for Tension Testing of Metalic Materials. 